\title{
GRAZING EFFECTS ON PASTURE AND ANIMAL PRODUCTION FROM OVERSOWN TUSSOCK GRASSLAND
}

Tara Hills Research Station, MAF, Omarama

\section{Abstract}

Continuous stocking was compared with intermittent (two paddock) and rotational (six paddock) grazing at low, medium and high stocking rates equivalent to $1.0 \mathrm{x}, 1.5 \mathrm{x}$ and $2.0 \mathrm{x}$ conventional rates for oversown tussock country (500 $\mathrm{mm}$ annual rainfall). 'By the sixth year liveweight gain/ha from Merino wether hoggets was improved $26 \%$ by intermittent and rotational grazing at medium stocking rates from that at conventional stocking rates. A strong interaction was demonstrated, with advantage in liveweight gain from intermittent and rotational grazing strengthening with increasing stocking rate.

Total vegetative cover $(75.8 \%)$ remained unchanged. Cocksfoot increased under low stocking while ryegrass increased under high stocking. A $60 \%$ overall loss in ryegrass during 1982 was attributed to unusually low winter soil temperatures. White clover cover was affected more b y climate than by grazing. A!!hough there were interim differences, herbage production by the sixth year was similar for all treatments.

Keywords: Tussock country, oversown, grazing, stocking rate, subdivision, pasture development, utilisation, Merino, liveweight.

\section{INTRODUCTION}

Oversowing with clovers, cocksfoot and ryegrass is the dominant form of agricultural improvement in the South Island high country. To date $14 \%(466,000 \mathrm{ha})$ has been improved by this method compared with only $4 \%(14,000$ ha) by other means including forestry (Kerr, 1983).

Problems associated with establishment of these traditional species have been largely resolved and dramatic increases in production immediately following improvement have been reported (O'Connor, 1966; Vartha \&Clifford, 1973). However, the continued tradition of set stocking this improved high country is inefficient in terms of conversion of feed into saleable animal products (Joyce, 1978).

Better utilisation is a low cost means for runholders to improve their pastoral efficiency. But how is this achieved in the high country environment? What are the long term effects of intensive grazing on pasture and animal performance? To what extent should oversown tussock country be subdivided?

A grazing experiment was started at Tara Hills in 1978 to answer such questions, and this paper summarises some of the results to date.

\section{MATERIALS AND METHODS}

\section{Design}

The 16 ha experiment is located on a steep $\left(30^{\circ}\right)$ mid-altitude $(760-930 \mathrm{~m})$ shady aspect of class VIle country with Omarama Steepland YGE soils (Ni! Soil Bureau, 1968). Low temperatures prevent pasture growth from mid-April to mid-October and the low annual rainfall of $500 \mathrm{~mm}$ results in a soil moisture deficit most summers.

The area was initially oversown with cocksfoot and clovers (cultivars not recorded) and topdressed in 1955, and prior to 1976 was intermittently stocked during the pasture growth season at the conventional rate of around $2.0 \mathrm{SU} / \mathrm{ha} / \mathrm{year}$ (Musgrave, 
1977). The area was again oversown in spring 1978 with a mixture including cocksfoot (Dactylis glomerata L. 'Grasslands Apanui'), ryegrass (Lolium perenne L. 'Grasslands Nui') and white clover (Trifolium repens L. 'Grasslands Huia').

Sward composition at the start of the study was consistent across the site. Blue

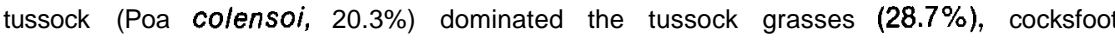
$(9.1 \%)$ dominated the inter-tussock grasses $(16.9 \%)$, and white clover $(8.4 \%)$ dominated the clovers (12.5\%). Other natives and adventives accounted for a further $17.7 \%$, giving a total standing vegetation of $75.8 \%$, the balance being detached litter $(13.4 \%)$ and bareground (10.8\%).

The unreplicated $3 \times 3$ factorial design compared continuous stocking with intermittent (a two paddock rotation with stock shifts approximately every three weeks) and rotational (six paddocks with weekly shifts) grazing at low, medium and high stocking rates. Annual stocking rates varied from year to year according to duration of pasture growth, however the low:medium:high ratio was always maintained. Merino wether hoggets (35 kg mean initial liveweight) were used, giving mean stocking rates over six years of 1.9, 3.0 and $4.1 \mathrm{SU} / \mathrm{ha} /$ year (one hogget $=0.5$ $\mathrm{SU}$ over November and December; one hogget $=1.0 \mathrm{SU}$ over January to April).

The hoggets were regularly drenched with anthelmintics and selenium and given continued access to mineral salt blocks. Sulphur-fortified superphosphate $(27 \% \mathrm{~S})$ was applied at $125 \mathrm{~kg} / \mathrm{ha}$ in 1978 and every second year as maintenance (Douglas \& Kinder, 1974).

Orthogonal contrasts were employed to test the significance of the main effects of stocking rate [low vs. high (a), medium vs. $1 / 2$ (low + high) (b)] and extent of subdivision [continuous vs. subdivisions (c), intermittent vs. rotational(d)] in addition to the interaction (a) $\times($ c). The remaining contrasts of the interaction were assumed a priori to be random variations.

\section{Pasture and Animal Measurements}

Vegetative cover was assessed from permanent transects each spring by point analysis, recording cover hits for all species (Radcliffe \& Mountier, 1964) in addition to litter, rock and bareground. During the grazing season pasture production (net herbage accumulation) and utilisation were determined for inter-tussock (all herbage except tussocks) and tussock separately using comparative visual assessment (Haydock and Shaw, 1975) calibrated by hand cut quadrats of all herbage available for grazing. On the continuous stocking treatments quadrat areas were regularly caged, allowing assessment of pasture production by difference. Percent utilisation was derived for each grazing as [(Pre HM . Post HM + NHA)/(Pre HM + NHA)] 100 where $\mathrm{HM}=$ herbage mass and $\mathrm{NHA}=$ net herbage accumulation. Fasted liveweights were recorded at the start of grazing and at the end of each rotation. Climate parameters were monitored at weekly intervals on site.

\section{RESULTS}

For simplicity, only main effects of stocking rate and extent of subdivision are presented, unless an interaction was apparent.

\section{Sward Composition}

Standing vegetation

After five years standing vegetative cover was not modified by grazing treatment.

Clover cover

Year to year response was greater (Figure 1) than any treatment effect. The overall threefold increase during the second year was a direct result of the moist growing season (soil moistures $46 \%$ above average). The collapse at low stocking rates the following year was attributed to a high porina (Wiseana spp) population 
which followed this favourable season. Numbers of pupae in October 1981 were greater $(P<0.05)$ under low $\left(42 / \mathrm{m}^{2}\right)$ than high $\left(7 / \mathrm{m}^{2}\right)$ stocking.

Inter-tussock grass cover

After three years total inter-tussock grass cover increased more $(P<0.01)$ at both low and high than at medium stocking rates (Table 1). Cover also increased more (PtO.O1) under rotational than intermittent grazing.

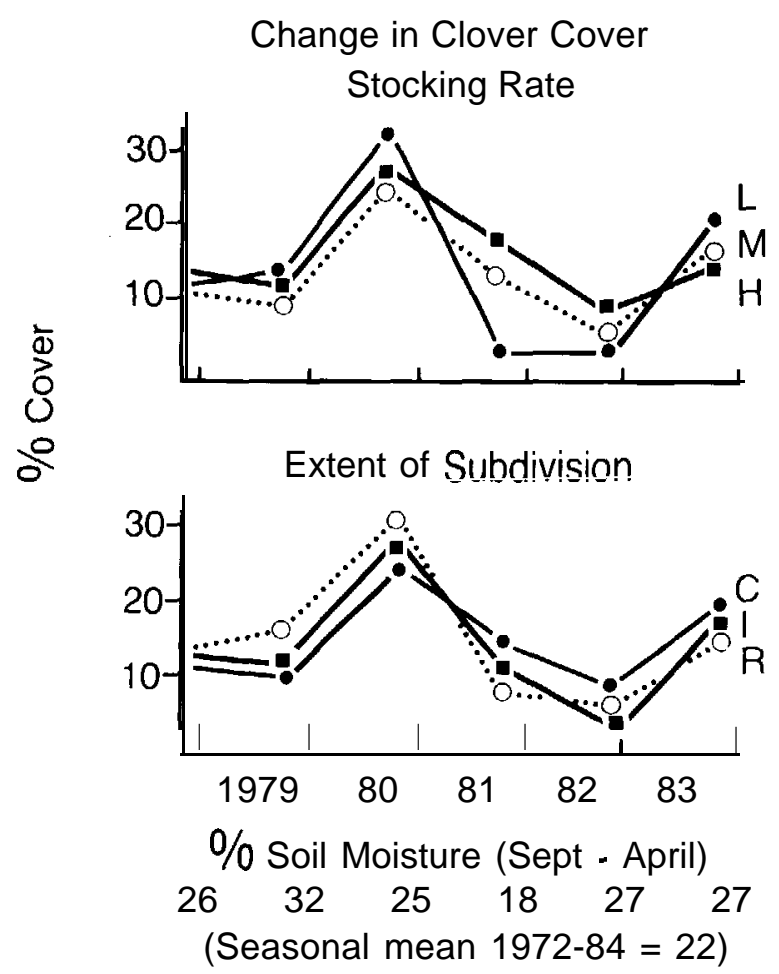

figure 1: Main effects of stocking rate and extent of subdivision on clover cover (spring pointings), and mean $0-10 \mathrm{~cm}$ gravimetric soil moisture (September to April inclusive). L low stocking rate; $M$ medium stocking rate; $H$ high stocking rate; $C$ continuous stocking; I intermittent grazing; $\boldsymbol{R}$ rotational grazing.

This response resulted from an interplay between cocksfoot and ryegrass (Grasslands Nui). Cocksfoot increased at low stocking rates but decreased at high rates $(P<0.01)$, and increased under rotational grazing but fell under continuous stocking $(P<0.01)$. In contrast ryegrass increased $(P<0.01)$ at higher stocking rates (Figure 2).

However, by year five (spring 1982) inter-tussock grass cover was reduced, especially under the high stocking rates. This was attributed to cold kill of ryegrass during July 1982 when record low soil temperatures occurred (Figure 3).

Tussock grass cover

The change in tussock cover appeared greater at high than at low stocking $(-14 \%$ cf. $-7 \%$ ground cover). However, this was not statistically significant due to interactive responses between stocking rate and extent of subdivision which were assumed as random variations by the analysis model. 
Table 1: CHANGE IN \% COVER OF INTER-TUSSOCK GRASS AFTER THREE YEARS (1978-81). INTER-TUSSOCK DM PRODUCTION (KG/HA) DURING GRAZING IN YEARS FOUR (1981182) AND SIX (1983184). MEAN UTILISATION PER GRAZING DURING YEAR SIX (1983184).

\begin{tabular}{|c|c|c|c|c|c|}
\hline \multirow[t]{2}{*}{ Treatment } & \multirow{2}{*}{$\begin{array}{l}\text { Change in } \\
\text { nter-tussock } \\
\text { grass } \\
1978-81\end{array}$} & \multicolumn{2}{|c|}{$\begin{array}{l}\text { Inter-tussock } \\
\text { DM production }\end{array}$} & \multicolumn{2}{|c|}{$\begin{array}{c}\text { Mean \% utilisation } \\
\text { per grazing } \\
(1983184)\end{array}$} \\
\hline & & 1981182 & 1983184 & Inter-tussock & Tussock \\
\hline low continuous & 2.5 & 1600 & 1840 & 37 & 18 \\
\hline low intermittent & 8.8 & 1170 & 1370 & 24 & 6 \\
\hline low rotational & 15.2 & 760 & 1450 & 28 & 6 \\
\hline medium continuous & -0.2 & 1130 & 1720 & 87 & 24 \\
\hline medium intermittent & -0.2 & 1250 & 1870 & 79 & 50 \\
\hline medium rotational & 7.4 & 1490 & 2550 & 73 & 18 \\
\hline high continuous & 8.1 & 1310 & 1890 & 94 & 61 \\
\hline high intermittent & 5.7 & 1980 & 1360 & 84 & 34 \\
\hline high rotational & 10.9 & 1850 & 2310 & 89 & 47 \\
\hline \multirow{2}{*}{ LSD main effects } & & 550 & 990 ns & 9.8 & $44 \mathrm{~ns}$ \\
\hline & 3.9 & & & 18.0 & \\
\hline SD interaction & 1.6 & 420 & 760 ns & & \\
\hline
\end{tabular}

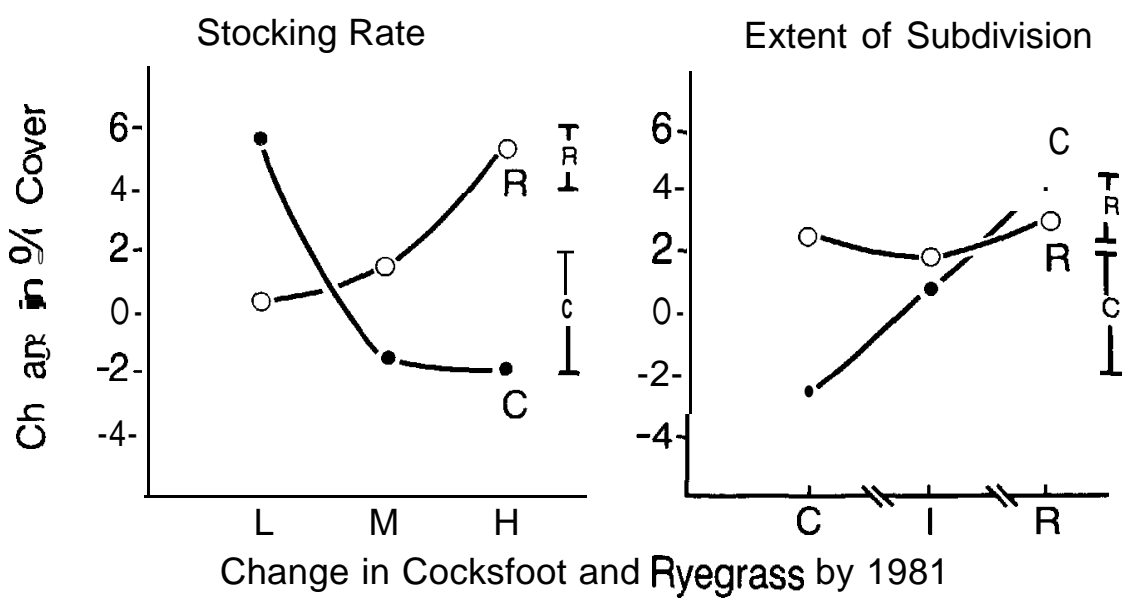

Figure 2: Main effects of stocking rate and extent of subdivision on change in cocksfoot and ryegrass cover after three years. C cocksfoot; $R$ ryegrass; LSD at $5 \%$.

\section{Sward Production}

By year four (81182) inter-tussock DM production displayed an interaction $(\mathrm{P}<0.05)$ with subdivision reducing production at low stocking rates but increasing production at high stocking rates (Table 1). However, this effect, although still apparent, did not reach significance subsequent to the 1982 winter.

Tussock production was $40 \%$ that of the inter-tussock species and was not modified significantly by grazing treatment. 


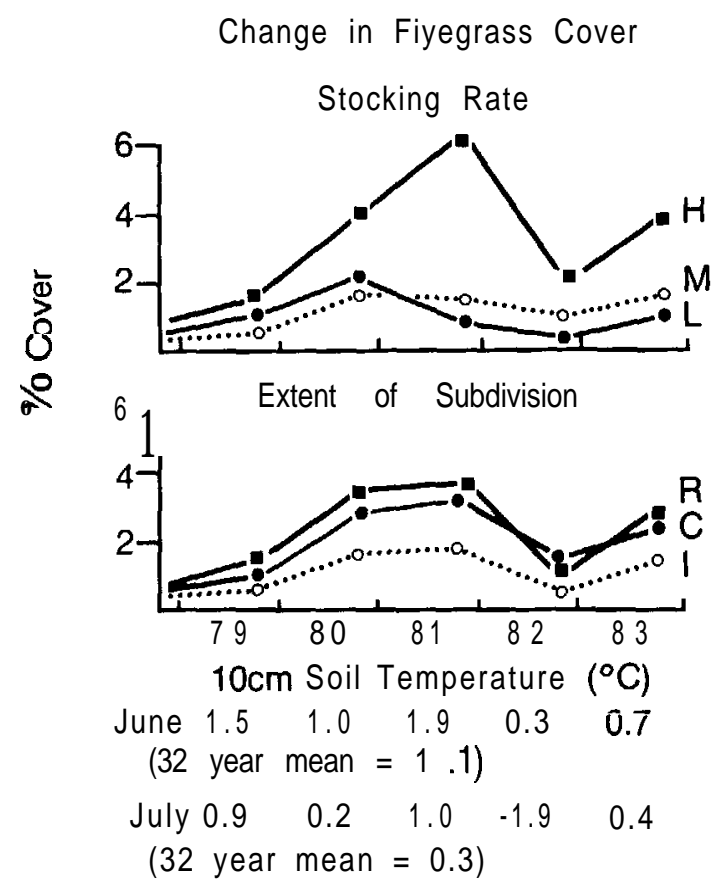

Figure 3: Main effects of stocking rate and extent of subdivision on ryegrass cover (spring pointings), and mean June and July $10 \mathrm{~cm}$ soil temperature ${ }^{\circ} \mathrm{C}$ (Tara Hi//s met. site.) L low stocking rate; $M$ medium stocking rate; $H$ high stocking rate; $C$ continuous stocking; I intermittent grazing; $R$ rotational grazing.

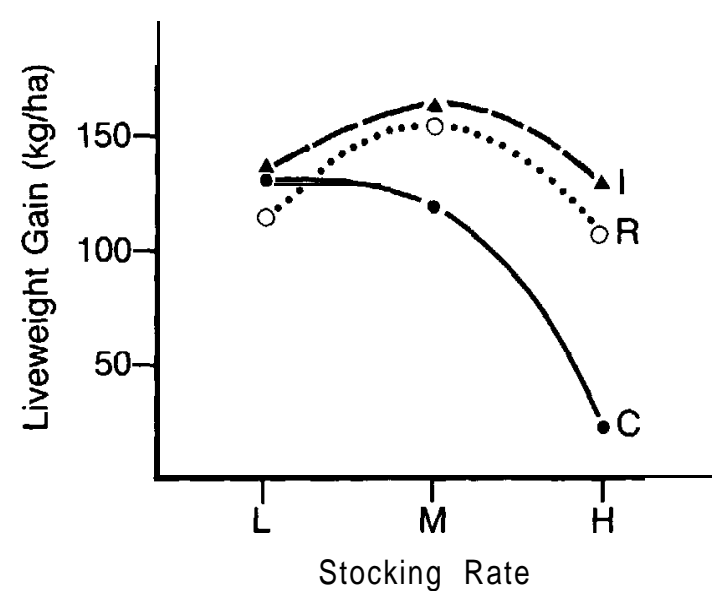

Effect on LWT gain during yr. 6 (1983/84)

Figure 4: Hogget liveweight response ( $\mathrm{kg} / \mathrm{ha}$ ) to stocking rate for different managements during the sixth year (1983/84). L low; M medium; C confinuoos stocking; I intermittent grazing; $\boldsymbol{R}$ rotational grazing; $L S D$ (main effects) $=2.43$ at $1 \% ; S D$ (interaction) $=10.2$. 


\section{Sward Utilisation}

By the sixth year (1983/84) mean inter-tussock utilisation per grazing was dramatically increased $(P<0.01)$ at high relative to low stocking (Table 1$)$. Most of this increase was gained by the medium rate. At all stocking rates continuous stocking resulted in higher $(P<0.05)$ mean utilisations than both intermittent and rotational grazing. Tussock was utilised to half the extent of inter-tussock, and here the response to increased stocking rate was linear $(P<0.01)$.

\section{Fasted Liveweights}

By the sixth year (1983184) liveweight gain/ha was greater $(P<0.01)$ at medium than at low stocking, which in turn was greater $(P<0.01)$ than that at high stocking (Figure 4). There was no difference between intermittent and rotational grazing but both produced more $(\mathrm{P}<0.01)$ per hectare than continuous stocking. However, the extent of subdivision interacted strongly $(P<0.01)$ with stocking rate, as there was no effect of subdivision at the low stocking rate.

\section{DISCUSSION}

The maximum liveweight gain/ha from intermittent grazing at the medium stocking rate in year six represents a $26 \%$ increase over that from conventional stocking rates regardless of management (Figure 4). This shows that the classical stocking rate/management interaction first reported by McMeekan (1960) can also occur for oversown tussock country. The improvement in liveweight gain was achieved by a single subdivision fence, and further subdivision gave no added advantage.

Better utilisation resulted from increased stocking rate rather than increased subdivision. However, it is clear that improved utilisation per grazing does not imply improved animal performance. Although not reported, both intermittent and rotational grazing allowed the generation of a bank of pasture ahead of grazing. The resulting lower utilisation under these treatments than under continuous stocking was due to this feed bank, rather than reduced herbage consumption. The high utilisations from high stocking rates reflect the measurement technique that assessed herbage mass available to grazing, not that above ground level.

The agronomic results from this study clearly demonstrate that the development of oversown tussock grasslands can be manipulated by grazing management. But they have also shown that climatic influences can effect greater change in one year than the grazing animal can in six.

In terms of sward development there are two distinct phases in this experiment. During the first phase, up until the 1982 winter, intensive grazing improved intertussock grass cover and inter-tussock production. However, the most significant sward response during this period was that of climate on white clover cover. None of the grazing treatments were able to maintain the increases in white clover that occurred during the favourable $1979 / 80$ season, suggesting an inability of this species to withstand selective grazing even at low levels of utilisation. This conflicts with evidence from North Island hill country where sheep did not preferentially select white clover (Clark et al. 1981). However, the incomplete ground cover or open nature of the Tara Hills sward may explain this difference.

The 1982 winter initiated the second phase in this experiment by retarding the improvement in ryegrass cover. Over $60 \%$ of the ryegrass was lost across all treatments but because more was present under high stocking rates, pasture and animal production was most affected at these rates. However, despite this set back the pre-1982 trends for ryegrass cover (Figure 2) are continuing.

The risk of ryegrass loss on shady faces and the poor response from white clover highlight the limitations of traditional plant material in this environment. In response to this, some 28 legumes and 26 grasses with emphasis on various white 
clover and ryegrass cultivars and ectotypes have been planted into the treatments of this experiment to assess long term grazing effects on persistence and spread.

To conclude, it is clear that this experiment is by no means completed. After six years a $26 \%$ increase in liveweight gain has been achieved by increased stocking rate and a single subdivision fence. However, because the sward development under intensive grazing has been interrupted by climate, I believe that this production advantage, although substantial, is far below the potential. To realise the full potential, however, the use of plant material better adapted to high country conditions is essential.

\section{ACKNOWLEDGEMENTS}

Thanks to M.J. Daly and staff at Tara Hills for technical assistance; to Prof. K.F. O'Connor, Lincoln College for valued discussion; and to Dr G.H. Jowett for biometric design.

\section{REFERENCES}

Clark, D.A.; Lambert, M.G.; Chapman, D.F. 1980. Proc. N.Z. Grass/d Ass. 43: 205214. Douglas, J.A.; Kinder, J.W. 1974. N.Z. J. exp. Ag. 3: 127-133.

Haydock, K.P.; Shaw, N.H. 1975. Aust. J. exp. Ag. Anim. Husb. 15: 663-670.

Joyce, P.J. 1978 Proc. Conf. Conservation High Mountain Resources (Lincoln College) p. 24-37.

Kerr, I.G.C. 1983. Proc. Hill High Count. Sem. (Lincoln College) p. 19-26.

McMeeken, C.P. 1960. Proc. 8th Int. Grassld. Congr. p. 21-26.

Musgrave, D.J. 1977. Tussock Grass/d. Mountain Lands. Inst. Rev. 35: 30-37.

N.Z. Soil Bureau, 1968. Soil Bureau Bulletin 27, Sheet 11.

O'Connor, K.F. 1966. Proc, N.Z. Grass/d Ass. 28: 59-78.

Radcliffe, J.E.; Mountier, N.S. 1964. N.Z. J. Bot. 2: 90-97.

Vartha, E.W.; Clifford, P.T.P. 1973. N.Z. J. exp. Ag. 1: 181-186. 